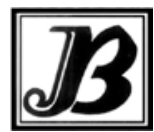

J. Bio-Sci. 28: 43-50, 2020

ISSN 1023-8654 http://www.banglajol.info/index.php/JBS/index DOI: https://doi.org/10.3329/jbs.v28i0.44709

\title{
MANAGEMENT PRACTICES IN THE BEEL AQUACULTURE SYSTEM AT RAJSHAHI, NORTHWEST BANGLADESH
}

\author{
S Akter, MR Ali and MMR Mondol* \\ Department of Fisheries, Faculty of Agriculture, University of Rajshahi, Rajshahi-6205, Bangladesh
}

\begin{abstract}
Open aquatic system such as beel is an important freshwater resource for agriculture and aquaculture. This study was conducted (July-December 2014) to describe the beel aquaculture management practices in the Hagla Beel at Bagmara upazila under Rajshahi district. The Beel fish farming area was 20.25 ha and irregular in shape with average depth $1.5 \mathrm{~m}$. During the study period, the measured water quality parameters of the beel were within the suitable range for aquaculture. Eight genera of phytoplankton and eight genera of zooplankton were identified from the beel water body. Four native and 4 exotic fish species with sizes ranging from $0.15-1.11 \mathrm{~kg}$ were stocked for growing in the beel. At the end of culture period, the production of fish was $2,622.15 \mathrm{~kg} / \mathrm{ha}$ and cost-benefit ratio (CBR) was 1:1.42. Environmental problems such as increasing of water temperature and decreasing of water level during summer, and parasitic diseases were some of the risks in beel fish farming system. The results of this study should be useful for beel aquaculture, and for the farmers and resource manager for harnessing maximum benefits from the beel resources in Bangladesh.
\end{abstract}

Key words: Aquaculture, Hagla Beel, Management practice, Northwest Bangladesh

\section{Introduction}

Fisheries, as one of the sub-sector of agriculture, is playing significant role in supplying nutrition, employment generation, reducing poverty and earning foreign exchange, and more importantly developing socioeconomic conditions in the rural areas of Bangladesh (DoF 2017). Fisheries sector contributes $3.65 \%$ to GDP and $23.81 \%$ to agricultural production. Bangladesh earns a considerable amount of foreign currencies every year by exporting fish, shrimps and other fisheries products (FRSS 2017). Bangladesh has extensive water bodies that have a high potential for fisheries production and appropriate management of the water bodies can increase the fish production by many folds.

Among all other open water bodies' beel is the most productive ecosystem (Ahmed et al. 1991). Beels are usually shallow and hold water throughout the year (perennial beels) but some beels retain water for 4-5 months (seasonal beel). Beels are usually rich in aquatic vegetation, and surrounded by paddy fields that provide food and shelter for the various species of fish and other aquatic organisms. In open water fisheries sector beels are playing a vital role regarding employment generation, animal protein supply, foreign currency and poverty alleviation. Over the last two decades fish production from the beel has been decline due to over fishing, siltation and management problems (Middendrop and Balarin 1999). Proper management of the beel could significantly contribute to the national fish production. Nowadays, aquaculture is being practiced in the beel area in different parts of our country. Still to date there is a lack of research information on beel aquaculture management. The present study was conducted to provide information about the aquaculture management practices in the Hagla Beel at Rajshahi, the northwest Bangladesh. The

*Author for correspondence: mostafiz_bau@yahoo.com 
specific objectives were to determine water quality parameters of the beel, document aquaculture management practices and analyze production economics of the beel fish farming.

\section{Materials and Methods}

\section{Study area}

The study site was located in Hagla Beel at Bagmara upazila under Rajshahi district, the northwest Bangladesh and the farming activity was observed for a period of 6 months (July-December, 2014). The beel was a perennial water body with an area of 20.25 ha, $1.5 \mathrm{~m}$ in depth and irregular in shape (Fig.1).

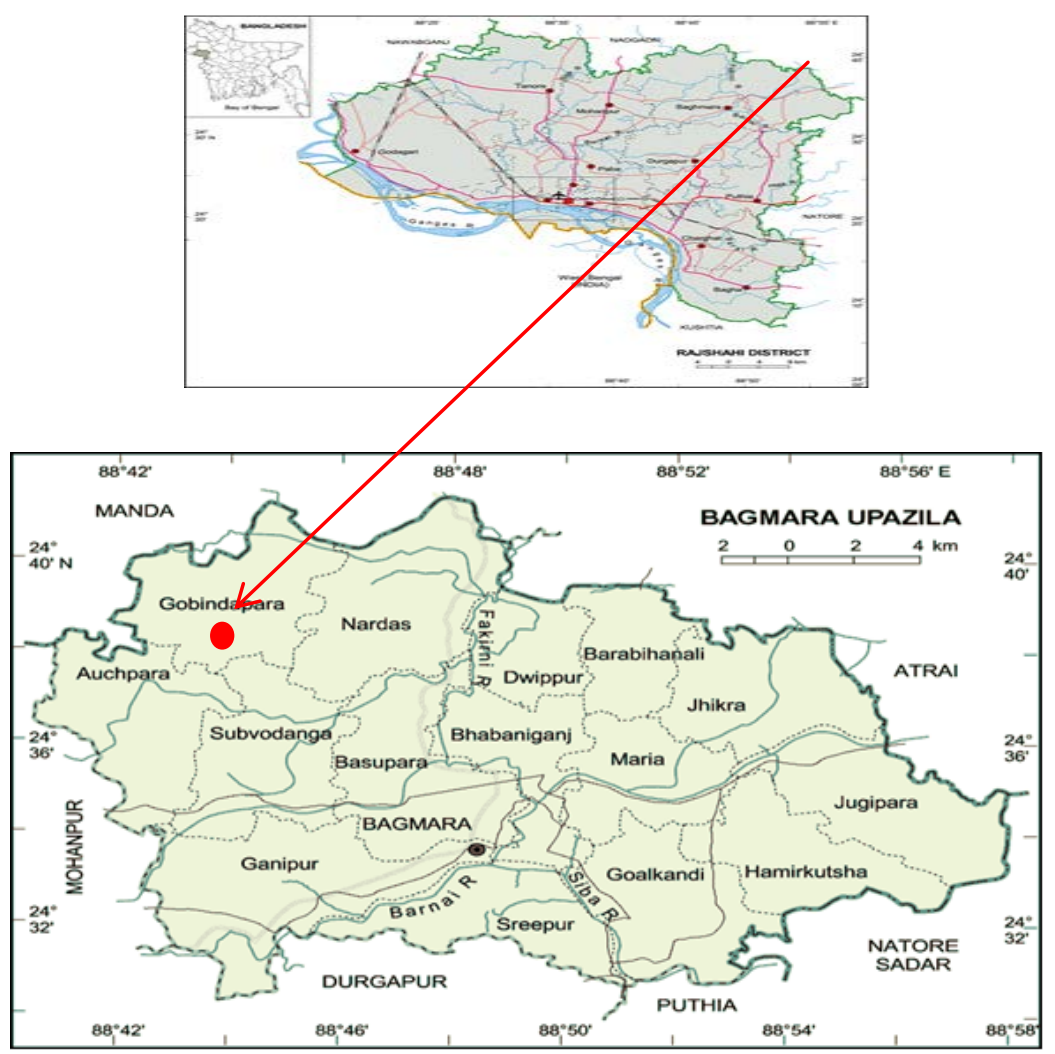

Fig. 1. Map showing the study area (O).

\section{Water quality parameter and plankton population}

Water quality parameters, like water temperature were measured by Celcius thermometer and transparency was measured by secchi disk. Dissolved oxygen (DO), free $\mathrm{CO}_{2}, \mathrm{pH}$ and alkalinity were measured by water quality test kit (HACH kit FF-2, USA). Plankton population was identified according to Prescott (1964). All the water quality parameters and plankton was collected on monthly basis. 


\section{Farming management}

\section{Pre-stocking management}

Bushes and shrubs were cleaned manually from the embankment and the broken parts of dyke repaired using sand bags. The aquatic weeds namely kochuripana, khudipana, topapana, kolmilata, malancha, kochu were controlled both biologically releasing phytophagus fishes and manually using bamboo and metal devices. The farmers did not use any chemical to control the aquatic weeds.

\section{Fish stocking}

Four native fish species (Labeo rohita, Gibelion catla, Cirrhinus mrigala and Notopterus chitala) and 5 exotic fish species (Hypophthalmichthys molitrix, Ctenopharyngodon idella, Cyprinus carpio, Aristichthys nobilis and Mylopharyngodon piceus) were stocked in the beel. Fingerlings were collected from fry trader of Rajshahi. Initial weight of fingerlings was measured and stocking was done in the early morning (Table 1).

Table 1. Fish species composition, initial weight and stocking density

\begin{tabular}{lccc}
\hline Fish species & Common name & $\begin{array}{c}\text { Initial weight } \\
(\mathrm{kg})\end{array}$ & $\begin{array}{c}\text { Stocking density } \\
\text { (fish/ha) }\end{array}$ \\
\hline Labeo rohita & Rui & $0.16 \pm 0.07$ & 300 \\
Gibelion catla & Catla & $0.55 \pm 0.11$ & 100 \\
Cirrhinus mrigala & Mrigel & $0.15 \pm 0.02$ & 200 \\
Notopterus chitala & Chitol & $1.11 \pm 0.45$ & 15 \\
Hypophthalmichthys molitrix & Silver carp & $0.23 \pm 0.02$ & 400 \\
Ctenopharyngodon idella & Grass carp & $0.54 \pm 0.09$ & 50 \\
Cyprinus carpio & Common carp & $0.32 \pm 0.01$ & 200 \\
Aristichthys nobilis & Bighead carp & $0.25 \pm 0.01$ & 150 \\
Mylopharyngodon piceus & Black carp & $0.53 \pm 0.0$ & 25 \\
\hline
\end{tabular}

\section{Post-stocking management}

The beels was monitored regularly and the liming was done at the rate of $62.5 \mathrm{~kg} / \mathrm{ha} / \mathrm{month}$. Inorganic fertilizer such as urea and TSP were applied at the rate of $267.5 \mathrm{~kg} / \mathrm{ha} / \mathrm{month}$ and $170 \mathrm{~kg} / \mathrm{ha} / \mathrm{month}$, respectively during the entire culture period (6 months). During the first two months supplementary feeds such as rice bran, wheat bran and mustard oil cake were used while the rest of the study period commercial feeds were provided to the fishes at 2-3\% body weight per day.

\section{Fish growth}

Fishes were sampled monthly. On each sampling day, individual fish was weighed to determine the fish growth and to adjust the feed ration. Growth and yield of fishes was calculated as follows:

Final weight $(\mathrm{g})=$ Weight of fish at harvest $(\mathrm{g})$.

Weight gain $(\mathrm{g})$ = Mean final weight $(\mathrm{g})$ - Mean initial weight $(\mathrm{g})$

Fish yield (kg/ha/12 months) = Fish biomass at harvest - Fish biomass at stock 


\section{Farming economics}

Data on both fixed and variable costs was recorded to determine the total cost (BDT/ha). Total return was determined from the market price of fish sale, expressed as BDT/ha. The net benefit and cost benefit ratio (CBR) was calculated as follows:

Net benefit $(\mathrm{BDT} / \mathrm{ha})=$ Total return $(\mathrm{BDT} / \mathrm{ha})-$ Total cost (investment) $(\mathrm{BDT} / \mathrm{ha})$

$\mathrm{CBR}=\frac{\text { Net benefit }}{\text { Total investment }}$

\section{Statistical analysis}

Data on water quality parameters and fish growth was subjected to one way ANOVA (Analysis of Variance) with Duncan Multiple Range Test using computer software SPSS (Statistical Package for Social Science, version-20.0) to know the level of significance at $p<0.05$.

\section{Results and Discussion}

\section{Water quality parameter}

Water quality parameters showed significant monthly variations $(p<0.05)$ and their mean values are shown in Table 2. The highest water temperature was recorded in the month of July $\left(28.39^{\circ} \mathrm{C}\right)$ and the lowest in the month of December $\left(20.39^{\circ} \mathrm{C}\right)$, which was more or less similar to the findings of Ehshan et al. (1996) who found highest water temperature $\left(31^{\circ} \mathrm{C}\right)$ in the month of June and the lowest $\left(25^{\circ} \mathrm{C}\right)$ in January from Chalan Beel, the northwest Bangladesh. In the present study, the highest transparency was recorded as $24.67 \mathrm{~cm}$ in August and the lowest was $22.19 \mathrm{~cm}$ in October. During the study period, the highest value of DO was 6.07 $\mathrm{mg} / \mathrm{l}$ in December and the lowest value was $2.98 \mathrm{mg} / \mathrm{l}$ in July. The mean DO of the present study was $4.25 \pm 1.17 \mathrm{mg} / \mathrm{l}$ which was more or less similar with the findings of Rahman and Hassan (1992), who reported $5.0 \mathrm{mg} / \mathrm{DO}$ in a productive water body. The levels of free $\mathrm{CO}_{2}$ ranged $8.49-10.99 \mathrm{mg} / \mathrm{l}$, where the highest value was recorded in the month of July and lowest in the month of December. The average value of free $\mathrm{CO}_{2}$ was $9.64 \pm 1.05 \mathrm{mg} / \mathrm{l}$. According to DoF (2017) suitable range of free $\mathrm{CO}_{2}$ is $<12 \mathrm{mg} / \mathrm{l}$. During the study period, water pH of the beel ranged from 7.10 (August) to 7.82 (November), indicated a slightly alkaline condition but suitable for fish culture. Similar findings were found by Saha et al. (2003) and Islam (2000). Alkalinity of the beel fish farming pond ranged from 110.00 to $115.67 \mathrm{mg} / \mathrm{l}$, where the highest value was recorded in the month of July and lowest in the month of November. The average value of total alkalinity was $113.61 \pm 2.55 \mathrm{mg} /$. Boyd (1998) reported the highest alkalinity level up to $150 \mathrm{mg} /$.l. Alikunhi (1957) reported that total alkalinity more than $100 \mathrm{mg} / \mathrm{l}$ should be present in high productive water bodies. On the basis of above facts, it can be accomplished that total alkalinity recorded in the present study was within limit for fish culture.

Table 2. Water quality parameters in the in the Hagla Beel

\begin{tabular}{lccc}
\hline Parameters & Minimum & Maximum & Mean \\
\hline Water temperature $\left({ }^{\circ} \mathrm{C}\right)$ & 19.23 & 31.50 & $25.16 \pm 3.16$ \\
Water transparency $(\mathrm{cm})$ & 21.00 & 26.00 & $23.48 \pm 1.47$ \\
Dissolved oxygen $(\mathrm{mg} / \mathrm{l})$ & 2.53 & 6.22 & $4.25 \pm 1.17$ \\
$\mathrm{pH}$ & 6.85 & 7.90 & $7.42 \pm 0.28$ \\
$\mathrm{CO}_{2}(\mathrm{mg} / \mathrm{l})$ & 8.30 & 11.50 & $9.64 \pm 1.05$ \\
Total alkalinity $(\mathrm{mg} / \mathrm{l})$ & 109.00 & 118.00 & $113.61 \pm 2.55$ \\
\hline
\end{tabular}




\section{Plankton population}

During the study four groups of phytoplankton (Cyanophyceae, Chlorophyceae, Euglenophyceae, Bacillariophyceae) in eight genera and two groups of zooplankton (Rotifera and Crustacea) in eight genera were identified (Table 3). Ahmed et al. (2004) also reported three groups of phytoplankton such as Myxophyceae, Chlorophyceae and Bacllariophyceae from a beel ecosystem of Brahmanbaria, Bangladesh.

Table 3. Identified phytoplankton and zooplankton genera in the Hagla Beel fish farming

\begin{tabular}{lll}
\hline Plankton & Genera & Class \\
\hline & Nostoc & Cyanophyceae \\
& Microcystis & Cyanophyceae \\
Anabaena & Cyanophyceae \\
Volvox & Chlorophyceae \\
Chlorella & Chlorophyceae \\
Spirogyra & Chlorophyceae \\
Euglena & Euglenophyceae \\
Navicula & Bacillariophyceae \\
\hline Keratella & Rotifera \\
& Branchionus & Rotifera \\
& Nauplius & Crustacea \\
& Diphanosoma & Crustacea \\
Daphnia & Crustacea \\
& Moina & Crustacea \\
& Cyclops & Crustacea \\
Diaptonus & Crustacea \\
\hline
\end{tabular}

Six genera of aquatic weeds floating, sub-merged and spreading were recorded in the beel during the study period (Table 4). Limited growth of aquatic plants is useful in maintaining water quality and serve as shelter and substrate for food organism in water body (Pillay 1990). On the other hand excess aquatic weeds used up the nutrients elements in the water body and decrease the productivity (Islam 1998). Therefore, the present study area was more or less hazard free from aquatic weeds.

Table 4. List of aquatic weeds found in the beel during the study period

\begin{tabular}{ccccc}
\hline $\begin{array}{c}\text { Sl. } \\
\text { No. }\end{array}$ & Local name & Type & Scientific name & Family \\
\hline 1 & Kochuripana & Floating & Eichhornia sp. & Pontederiaceae \\
2 & Topa pana & Floating & Pistia sp. & Anaceae \\
3 & Khudipana & Floating & Lemna sp. & Lemnaceae \\
4 & Kachu & Emergent & Colocasia sp. & Anaceae \\
5 & Kolmilata & Spreading & Ipomoea sp. & Convolvulaceae \\
6 & Helencha & Spreading & Enhydra sp. & Compositae \\
\hline
\end{tabular}




\section{Fish health management}

Parasitic diseases (Fig. 2) were more prominent during the winter months that hampered the fish production in the beel Hagla. The farmer used different types of chemicals (Calsium carbonate, Malakhite green, Potassium permanganate) to control parasitic diseases. Bauer (1961) reported that parasites can affect fish population by causing mortality, reduction in growth, weight loss and suppression of reproduction activity.
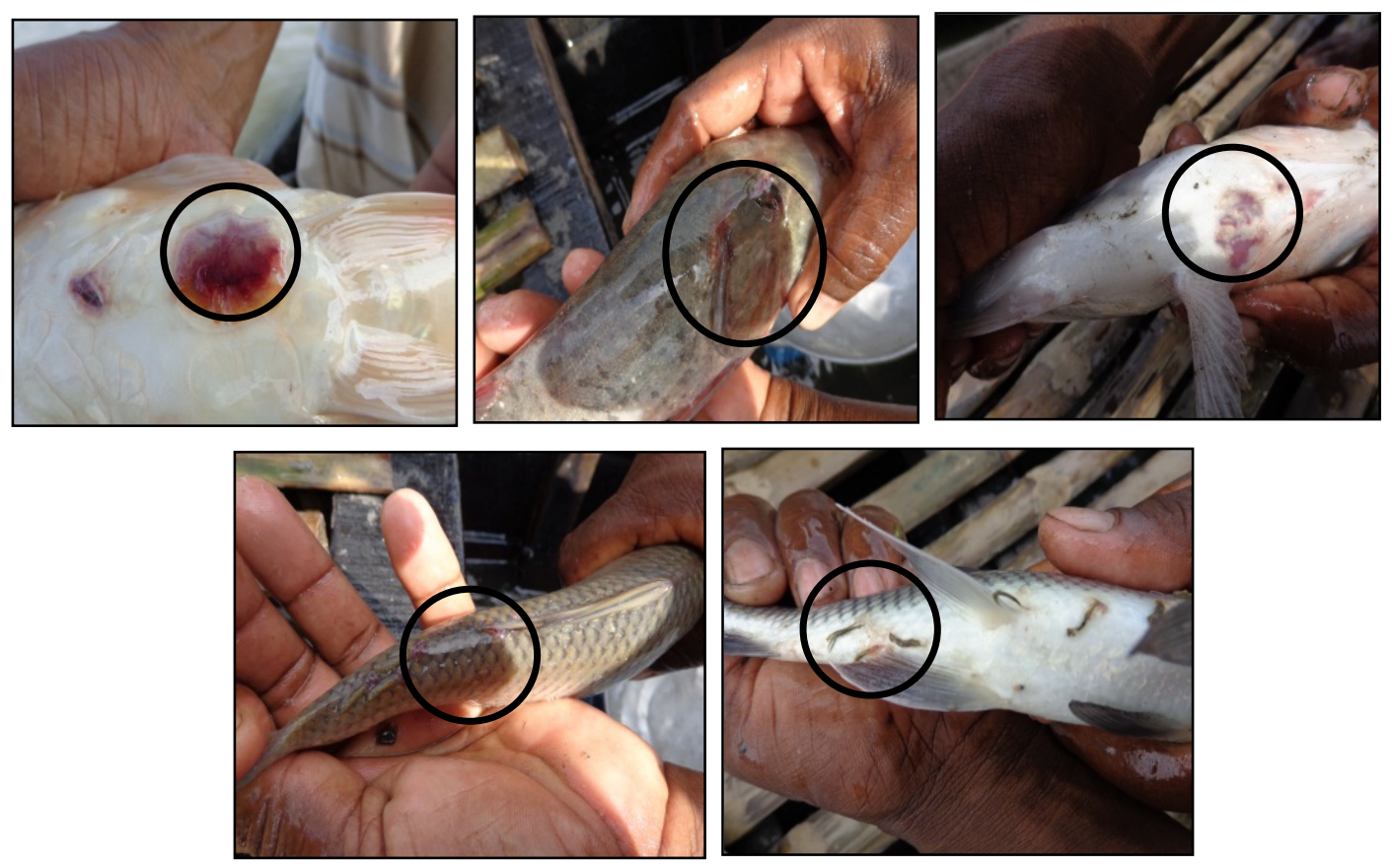

Fig. 2. Showing parasitic infestation in cultured fishes of the beel.

\section{Fish yields}

Table 4 represents the mean final weight and mean weight gain of cultured fishes during the study period. Highest final weight was obtained in C. idella $(3.11 \mathrm{~kg})$ and lowest from $H$. molitrix $(1.28 \mathrm{~kg})$. The highest yield was recorded in $H$. molitrix $(492.15 \mathrm{~kg} / \mathrm{ha})$ and the lowest in $M$. piceus $(52.75 \mathrm{~kg} / \mathrm{ha})$. Total fish production for the six months culture periods was $2622.15 \mathrm{~kg} / \mathrm{ha}$. Chandra et al. (2010) recorded 2920.43 $\mathrm{kg} / \mathrm{ha}$ fish production in beel aquaculture from Daudkandi, Cumilla, Bangladesh which is higher than the production of present study. The parasitic infection could be linked with the lower fish production in the present study as compared to the earlier study. 
Table 5. Production in the Hagla Beel fish farming pond

\begin{tabular}{lccc}
\hline Fish species & $\begin{array}{c}\text { Mean final weight } \\
(\mathrm{kg})\end{array}$ & $\begin{array}{c}\text { Mean weight } \\
\text { gain }(\mathrm{kg})\end{array}$ & Total production (kg/ha) \\
\hline Labeo rohita & 1.55 & 1.39 & 465.5 \\
Gibelion catla & 2.16 & 1.61 & 216.25 \\
Cirhinus mrigala & 2.23 & 2.08 & 446.25 \\
Hypophthalmichthys molitrix & 1.28 & 1.05 & 492.15 \\
Ctenopharyngodon idella & 3.11 & 2.5 & 155.5 \\
Aristichthys nobilis & 2.12 & 1.87 & 318.75 \\
Mylopharyngodon piceus & 2.11 & 1.5 & 52.75 \\
Cyprinus carpio & 2.53 & 2.21 & 442.75 \\
Notopterus chitala & 2.15 & 1.04 & 32.25 \\
\hline \multicolumn{2}{c}{ Total production } & 2622.15 \\
\hline
\end{tabular}

\section{Cost-benefit analysis}

Cost of fishes, feeds, fertilizers, insecticides and labors for different operations were the main variable costs, while land lease cost was considered as fixed cost. The cost of this culture system was BDT 235,120.50/ha, income was BDT 498,180.75/ha and return was BDT 302,390.25/ha. The calculated CBR was 1: 1.44 that means 1.44 BDT return comes from $1 \mathrm{BDT}$ investment. According to Chandra et al. (2010) the cost of fish production, total return and net income were BDT 115,308.55, BDT 176,385.49 and BDT 61,076.94/ ha, respectively, and CBR was 1:1.53, which is more or less similar with the present findings.

\section{Conclusion}

The findings of the present study clearly indicated that fish culture in beel is profitable. A further comprehensive research is necessary for the development beel aquaculture in Bangladesh.

\section{Acknowledgement}

The authors are grateful to the Fish Farmers of Hagla beel, Bagmara Upazilla for their important information and cordial help during the study. The authors are also thankful to the Department of Fisheries, University of Rajshahi to facilitate the research.

\section{References}

Ahmed KK, Halder GC, Hossain MM and Paul SK (1991). Macrobenthic fauna of Kaptai Lake (Bangladesh). Indian Journal of Fisheries, 38(3): 173-176.

Ahmed KKU, Hasan, KR, Ahmed SU and Mustafa G (2004). Ecology of Shakla beel (Brahmanbaria), Bangladesh. Bangladesh Journal of Fisheries Research, 8(2): 101-111.

Alikunhi KH (1957). Fish culture in India. Farming Bulleting of the Indian Council of Agricultural Research, vol. 20, pp.144.

Bauer ON (1961). Parasitic diseases of cultured fishes and methods of their prevention and treatment. In: Dogiel VA, Petrushevski GK and Polyanski YI. (eds.). Parasitology of Fishes. Oliver and Boyd, Edinburgh, UK, pp. 265-298. 
Boyd CE (1998). Water quality for pond aquaculture. Aquaculture Research and Development series no. 43. Aubura University, Alabama, USA, pp. 37.

Chandra AJ, Sarker D, Khaleque MA and Das DR (2010). Economic analysis of floodplain aquaculture at Daudkandi upazila in Comilla. Journal of Bangladesh Agricultural University, 8(2): 323-332.

DoF (2017). Matshaw Shaptahah Shankalon. Department of Fisheries, Ministry of Fisheries and Livestock, GOB (Bengali), pp. 155.

Ehshan MA, Hossain MS, Mazid MA, Mollah AFA, Rahman S and Razzaque A (1997). Limnology of Chanda Beel. Bangladesh Journal of Fisheries Research, 1(1): 31-40.

FRSS (2017). Yearbook of Fisheries Statistics of Bangladesh. Fisheries Resources Survey System (FRSS). Department of Fisheries, Bangladesh. Vol. 33, pp.124.

Islam MZ (2000). Enhancement of floodplain fisheries: experience of the Third Fisheries Project. In: Middendrop, HAJ, ThompsonP and Pomeroy RS (editors) sustainable inland fisheries management in Bangladesh. ICLARM Conference Proceedings 58: 209-218.

Islam Z (1998). A socio-spatial analysis of Beel Dakatia, Khulna University, Khulna.

Middendrop HAJ and Balarin JD (1999). Fisheries enhancement and participatory aquatic resources management: two types of management in the ox-bow lakes in Bangladesh. In: Middendrop HAJ, Thompson P and Pomeroy RS (editors) sustainable inland fisheries management in Bangladesh. ICLARM Conf. Proceedings, Manila, 58: 31-34.

Pillay TVR (1990). Aquaculture principles and practices. 1st ed. British library. pp. 526.

Prescott GW (1964). Algae of Western Great Lakes area. Wm. C. Brown Co. Dubuque, IOWA. pp. 946.

Rahman MA (2006). Banglapedia. Asiatic Society of Bangladesh, Dhaka.

Rahman MM and Hassan MR (1992). A study on fish and fishermen of Kaptai Lake in Bangladesh. Report submitted to University Grand Commission, Dhaka. pp. 49.

Saha BK and Hossain MA (2002). Saldu beel fishery of Tangail Banfladesh. Bangladesh J. Zoology, 30(2): 187-194.

Sarker MR and Islam MS (2011). An economic study of small scale Koi (Anabas. Testudineus) Fish farming in some selected areas of greater Mymensingh district. Bangladesh Journal of Political Economy, 27: 287-295.

(Manuscript received on July 19, 2019 and revised on September 22, 2019) 